\title{
IAMJ
}

INTERNATIONAL

AYURVEDIC

MEDICAL JOURNAL

Case Report

ISSN: 23205091

Impact Factor: 5.344

\section{AN AYURVEDIC APPROACH ON DARUNAKA - A Case Report}

\section{Sruthi O}

PG Scholar, Department of Kayachikitsa, KVG Ayurveda Medical College, Sullia, Karnataka, India

Corresponding Author: dr.sruthi.sreedhar@gmail.com

https://doi.org/10.46607/iamj4008112020

(Published online: November 2020)

Open Access

C International Ayurvedic Medical Journal, India 2020

Article Received: 31/10/2020 - Peer Reviewed: 08/11/2020 - Accepted for Publication: 16/11/2020

(D) Check for updates

\section{ABSTRACT}

In the present era, Dharunaka is a common condition mostly affecting children to middle aged people due to improper lifestyle, lack of hygiene and stress. There is no specific etiology explained in Any Ayurvedic texts. Dharunaka can be compared with seborrhoeic dermatitis / Dandruff in contemporary science. Maintenance of proper hygiene is the most important thing in this disease. Otherwise the chances of recurrence are more. With Ayurvedic formulations we can give good result in this condition. A 30-year-old male patient with chief complaint of itching on the scalp, dryness on scalp and hairfall came to our hospital and herbal medicines like Aragwadadi Kashayam (orally), Triphala Choornam (external), Tankanabasma, Manjishtadi Kashayam, Prapoundarika Tailam were given and procedures like Shiroabhyanga with Durdoorapathradi oil and Nasya with Prapoundarikadi oil also given. This medication was found very effective in controlling signs and symptoms of Dharunaka and improving the overall condition of the scalp. The improvement provided by the treatment is assessed on the basis of sign and symptoms before and after the treatment.

Keywords: Dharunaka, Dandruff, Aragwadadi Kashayam, Manjishtadi Kashayam, Triphala Chornam, Tankana Basma, Prapoundarikadi oil. 


\section{INTRODUCTION}

Darunaka is a common problem in day to day life. It is one among the nine types of Kapalagata Rogas. ${ }^{1}$ Kapala is the region which covers the skull. It is not counted in Shiroroga but explained as Kapalagata Roga by Vagbhata, Sarangadhara, Bhaishajya Ratnavali and Chakradatta. Susrutha has described this disease as a Kshudra Roga due to the vitiation of Vata and Kapha with symptoms like Kandu, Kesachyuti, Swapna, Rookshatha and Twaksputana. It can be correlated with dandruff in contemporary science. Darunaka means difficult to bear or tolerate, it is characterized by Twak Sputana, Kandu, Rookshatha, Keshachyuti. $^{2}$ Charaka has mentioned that the excessive use of Amla Ahara, Ahitha Ahara and Guru Ahara are the important causative factors of Shiroroga. Shiro Abhyanga is essential for preventing Darunaka. ${ }^{3}$ In the absence of that leads to dry scalp because of increase of Rooksha Guna of Vata. The unhygienic condition of the body is one of the main causes of itching. Daily bath is essential to avoid dirt, dust and waste products accumulating over the scalp. Due to improper Ahara-Vihara, Kapha and Vata vitiation takes place, which leads to Rasa-Raktha Dhatu vitiation and produce Srothorodha and finally result in Darunaka. Darunaka is curable as it limits itself in Twak. Even though it is curable, the rate of recurrence is high, owing to the negligence of proper hygiene and such other factors. Treatments include Shodhana and Shamana therapies. Darunaka can be correlated with seborrhoeic dermatitis based on the signs, symptoms and patho-physiology. Seborrhoeic dermatitis, an irritative disease of scalp and itching is its cardinal feature. Dandruff may be caused by different factors, but the exact underlying cause of Dandruff is unknown. Possible causes like using spray, gels, hair colouring products, cold weather, stress, anxiety, infrequent shampooing, inadequate cleaning, hormonal imbalance etc. ${ }^{4}$ A 30 -year-old male patient came to the KC OPD of KVG Ayurveda Medical College, with chief complaint of itching on the scalp, dryness on scalp and hairfall. In this case, herbal medicines like Aragwadadi Kashayam (orally), Triphala Choornam (external), Tankanabasma, Manjishtadi Kashayam,
Prapoundarika Tailam were given and the patient got good result. This medication was found very effective in controlling signs and symptoms and improving the overall condition of the scalp. The present study made an effort to understand the effect of Ayurvedic formulations in Darunaka. Dandruff can be considered as Darunaka in Ayurveda. And it is classified under Kshudraroga or Kapalagata Roga.${ }^{\mathbf{5}}{ }^{6}$ It is a general condition in which excessive shedding of dead skin from the scalp. It is a noninfectious skin disease of scalp. White dust like substances are found even in face, ears, body folds, neck and front of chest. Apart from being a physical condition, dandruff is also associated with social and self-esteem problems in many individuals. Although it is a minor problem, if not treated it can lead to Hair loss, Seborrheic dermatitis, Blepharitis. Seborrheic dermatitis is a chronic inflammation of skin which produces a red scaling, occasionally weepy, oozy eruption. Seborrheic dermatitis can affect the scalp as well as other seborrheic areas and involves itchy and flaking or scaling skin, inflammation and pruritis. ${ }^{7}$

There is no specific etiology narrated for Darunaka in Ayurveda hence Siroroga Nidanas can also be considered. Asathmendriya Arthasamyoga, Pranjaparadha, and Parinama are the basic causes pertaining to pathogenesis. Mainly Kapha and Vata get vitiated. The association of Pitta and Raktha is mentioned by Videha Acharya. Twak is formed from Raktha Dhatu during the time of Dhatuparinama. According to Arasaasrayi Bhava of Dosha and Dushya, the Pitta is vitiated in Darunaka. Raktha is also vitiated. Here the Sannikrishta Nidana is the vitiation of Kapha and Vata. The vitiated Doshas circulate through the blood vessel and reach the scalp. The vitiation and circulation of Doshas contribute in the progression of disease through Chaya, Prakopa and Prasara stages of disease, later in Sthanasamsraya Dosha interact with the Dushyas, Rasa-Raktha at Kapala in the disease Darunaka. As a result, the vitiated Kapha and Vata produces Kandu, Keshachyuti, Swapa, Rookshata and Twaksputana and manifest the disease Darunaka. The main Srothas vitiated here is 
Swedavaha Srothas. Swedavaha Srotho Dushti Lakshanas like itching, dryness of skin, abnormalities of touch sensation etc will be developed. These symptoms are seen in the Vyaktha stage of Darunaka. And the disease manifested. Poorvaroopa indicates the symptoms that manifest incompletely before the Vyakthavastha. No reference available regarding Poorvaroopa of Darunaka in the classics.

Darunaka can be differentiated among Kapala Vyadhi especially from Indralupta, Arumshika. In Darunaka the region of hairs loss has no specific shape. It spread all over head. But in case of Indralupta, the region of hair loss has specific shape. In case of Arumshika Sarshapavath Pidakas are seen in this disease. Maintenance of personal hygiene is the most important in this disease. The aim of treatment is controlling the Dandruff and preventing hair loss. The improvement provided by this therapy is assessed on the basis of signs and symptoms before and after treatment. The medication was found safe and effective in controlling signs and symptoms and improving the overall condition of scalp.

Case History: The 30-year-old male patient presented for the treatment of Darunaka. He complained of itching and dryness of the scalp, appearance of white substance in the scalp and hair fall. He is a software engineer and had stressful life. The complaint started one year back, and he used so many medicines, and got symptomatic relief, since one month the frequency of symptoms increased. Anti-dandruff shampoo gives temporary relief from itching and hair fall. He came to our hospital for better treatment.

Past History: There is no relevant past history.

Drug History: Nothing specific.

Family History: Nothing specific

Table 1: Personal History

\begin{tabular}{|l|l|}
\hline Diet & Mixed \\
\hline Bowel & Normal \\
\hline Appetite & Normal \\
\hline Micturition & 5-6 times, Slight yellow \\
\hline Sleep & Sound \\
\hline
\end{tabular}

\section{General examination:}

On inspection-:

- White powders on scalp, eyebrows and shoulder.

- Dryness on the scalp

Systemic examinations: Nothing specific

Investigation: $\mathrm{Hb}$ and $\mathrm{ESR}$ are normal.
Dandruff is easily detected. The condition is characterised by the appearance of white flakes on hair, shoulders and collar. With a proper clinical examination, it can be easily differentiated from conditions like psoriasis, Ringworm infection etc.

\section{Ayurvedic Examination}

Table 2: Dasavidha Pareeksha

\begin{tabular}{|l|l|}
\hline Prakrithi & Pitta-vata \\
\hline Viiti & Kapha-vata \\
\hline Satwa & Madhyama \\
\hline Sara & Madhyama \\
\hline Samhanana & Madhyama \\
\hline Pramana & Madhyama \\
\hline Satmya & Sarvarasa \\
\hline Ahara Shakthi & Uthamaa \\
\hline Vyayama Shakthi & Madhyama \\
\hline Vaya & Madhyama \\
\hline
\end{tabular}


Table 3: Ashta Vidha Pareeksha

\begin{tabular}{|l|l|}
\hline Nadi: & Vata- pitta \\
\hline Mutram: & 5 to 6 times, yellow colour \\
\hline Malam: & 1 to 2 times \\
\hline Jihwa: & Liptha (coated) \\
\hline Sabdha: & Spashta \\
\hline Sparsha: & Ushna \\
\hline Drik: & Samanya \\
\hline Akrithi: & Madhyama \\
\hline
\end{tabular}

\section{Nidana Panchaka}

Nidana: Improper cleaning of the scalp and hair, emotional stress, excessive intake of sugar, fat etc.

Poorvaroopa: itching mild, dryness of scalp

Roopa: Kandu, Twaksputana, Rookshatha, Keshachyuti.

Table 4: Samprapti Ghatakas

\begin{tabular}{|l|}
\hline Dosha \\
\hline Dushya \\
\hline Srothas \\
\hline Adhishtana \\
\hline Vyakthastana \\
\hline
\end{tabular}

\section{Treatment}

1. Aragwadadikashayam-: $15 \mathrm{ml}$ Kashayam $+60 \mathrm{ml}$ lukewarm water morning and evening on empty stomach.

2. Durdoorapathradi oil-: For Shiro Abhyanga .

3. Prapoundarikadi oil-: For Nasya, 6 drop for 14 days.

4. Manjishtadikashyam-: $15 \mathrm{ml}$ Kashayam $+60 \mathrm{ml}$ lukewarm water, morning and evening on empty stomach.

5. Arogwavardhini vati -: 1-tab morning and evening

6. Triphalachoornam with Shudhatankana-: For external use

\section{Scalp Care:}

- Patient is advised proper hygiene and care of scalp.

- Practice of Yoga and Meditation.

- After treatment patient got good result.

- For daily use, Triphaladi Keratailam was given.

First 15 days: The treatment started with Aragwadadikashayam, because patient had severe
Upashaya: Oil application

Anupashaya: Sweating

Samprapti: Nidana Kapha-Vata, vitiation vitiates Rasa-Raktha Dhatus, vitiation of Rasa-Rakthavaha Srothas, Srothorodha Stanasamsraya in Kapala Darunaka

Kaphavata
Twak, Raktha
Swedavaha
Kapala
Kapala

itching. Kapha Lakshanas were more and Kapalapradesha is predominant of Kaphadosha ${ }^{8}$ The ingredients in Aragwadadikashaya reduces Kaphadosha and most of them act on skin. ${ }^{9}$ It has antibacterial, antimicrobial, antiparasitic properties. So, it is helpful for all types of skin disease. Durdoorapathradi oil: It is a very good medicine for dandruff.${ }^{10}$ Here vitiation of Vata is more because of which excessive dryness is seen. Practice of Abhyanga mentioned in Dinacharya seems to be the Upashaya for Darunaka. Abhyanga Dwesha is a reason for Darunaka here Abhyanga specifically involves Shiroabhyanga approximately 12 to 20 minutes daily morning. It is best to remove dryness. Charaka mentioned excessive use of Amla Ahara, Ahitha Ahara and Guru Ahara are the important causative factor of Shiroroga. ShiroAbhyanga is essential for preventing Darunaka. In the absence of that leads to dry scalp because of increase in Rooksha Guna of Vata. Soft and gentle massage in Kapalapradesha with fingertips improves 
blood circulation. And Snigdhata in oil pacifies dryness thereby preventing shedding of scales and hair fall.

\section{Prapoundarika Taila Nasya}

This oil is useful in preventing hair fall, strengthening hairs and nourishing hair roots. It mainly pacifies Pitta and then effectively against Vata. It is useful in Pitta Prakrithi person with Pitta dominance symptoms. Here patient is Pitta dominant Prakrithi. ${ }^{11}$ Nasya is very effective and useful in all Urdwagathrugata Vyadhis. ${ }^{12}$ Ayurveda suggest Nasya is the one of the best therapies for hair loss. Siroabhyanga and Nasya reduce the symptoms of Darunaka and helps in prevention.

\section{Next 15 days}

Manjistadikashayam: Manjishtadikashayam is very effective in management of Vata Vikara associated Kapha Doshas and good for skin disease. Manjishtadikashayam is Madhura, Tiktha, Kashaya Rasa, Guru Ruksha Guna, Ushna Virya, Katu Vipaka, it is useful for improving blood circulation on the scalp and promotes cleaning of debris. ${ }^{13}$ Triphala is Tridosahara and Rasayana, internally and externally with Tankana Bhasma, prevents the scaling of scalp. Triphala Choornam is good for skin disorders and it is a blood purifier. Tankana ${ }^{14}$ with Katu Rasa, Ruksha Tikshna Guna, Ushna Virya, Katu Vipaka, Varnakara, Vishahara, Kandughna, Krimighna, Kleda Shamaka, Vatashamaka. This helps to clean off the debris and prevent the scalp from secondary invasion of microbial growth. Hairwash with Triphalachoorna and Tankana. Arogyavardhinivati:

This formulation is explained in Rasaratnasamuchaya in the context of Kushta (skin disease). ${ }^{15}$ It is Tridoshahara and good for all types of skin diseases. With these Ayurvedic formulations, symptoms were controlled successfully. And the patient was advised to continue yoga and meditation to reduce stress. Along with that Triphala Tailam (Sahasrayogam Tailayoga prakarana 44) for Siroabhyanga. It is Tridosahara, helpful in improving hair strength and reducing hairfall.

\section{Result:}

- Severity of Kandu significantly reduced after treatment.
- Dryness in Kapalapradesha and shedding of scales were reduced.

- Hair fall was also reduced.

\section{DISCUSSION}

Dandruff is the most common condition that affects the scalp. It is a natural process involving shedding of dead skin from the scalp. Although it is a minor problem, when the shedding occurs at an excessive rate it may cause problems. ${ }^{16}$ Excessive or severe dandruff with itching is known as Seborrheic dermatitis. It affects the scalp, forehead, naso-labial folds, eyelashes, eyebrows, and skin behind the ears, trunk and flexures. It requires medical treatment. Kandu is a symptom of vitiated Kaphadosa and it has an important role in the pathogenesis of Darunaka. This is due to the factors like accumulation of Malas on the scalp and the excessive secretion of sweat etc. Keshachyuti is caused by vitiated Pitta in association with Vata. The hair fall in Darunaka may occur due to lack of Snigdhata because of vitiated Vata, there by hairs become dull and rough. Owing to their abnormal dryness they become friable, short and thin that easily falls out. Swapa or abnormality of touch sensation means temporary or partial loss of sensation which is resulted due to the vitiation of Vata.

Rookshatha gets aggravated along with Vatadosa. Abhyanga Dvesha and other Vata vitiating Nidanas can lead to roughness of scalp. Susrutha has quoted Darunaka as Kathina and Karkasha. Sphutana is the breaking or splitting of scalp which is one of the symptoms of Darunaka. It occurs owing to scratching and abnormal keratinization of epidermis. It is also further due to the vitiated Vatadosha.

\section{CONCLUSION}

The prognosis of Darunaka is included in Sadhya stage according to Vagbhata. This case report includes Ayurvedic management of internal and external medicines for Darunaka. We found this treatment is safe and effective in Darunaka. And it improves the quality of life of the patient. The Ayurvedic management of Darunaka has a strong possibility to breakdown the pathogenesis of this disease. The 
recovery in this present case was promising and worth documenting. Dandruff responded very well to treatment but will commonly reoccur when the treatment is stopped. So, maintaining personal hygiene is a very important factor.

\section{PREVENTIVE MEASURES}

Advice to maintain proper hygiene., Preventive measures like healthy balanced diet., Avoiding excessive use of salt, sugar and alcohol., Proper hygiene., Regularly disinfecting towel, comb and pillow cover after use., Avoid use of harsh cosmetics on hair (dyes, gels, sprays etc.), In dry dandruff warm oil treatment can be given. Avoid stress by practicing yoga and meditation.

\section{REFERENCES}

1. Illustated AgadaTantra by Dr. P.V.N.R Prasad MD (Ayu), Chaukhamba Sanskrit Series Office, Varanasi, Edition 2 $2^{\text {nd }} 2013$, Page No 265.

2. Vagbhata Ashtanga Hridaya with Sarvanga Sundara commentary by Arunadatta and Ayurveda Rasayana of Hemadri, edited by Hari Sadasiva Sastri Paradakara, published by Chaukhamba Surbharathi Prakashan, Reprint 2010, Uthara sthana Chapter 23, Shloka 20, Page No 859.

3. Vagbhata Ashtanga Hridaya with Sarvanga Sundara commentary Arunadatta and Ayurveda Rasayana of Hemadri, edited by Hari Sadasiva Sastri Paradakara, Published by Chaukhamba Surbharathi Prakashan, Reprint 2010, Sutra Sthana, Chapter 22, Shloka 23, Page No 301.

4. http;//en.wikipedia.org/wiki/dandruff.

5. Susruta Susrutha Samhitha with Nibandasangraha commentary of Sri Dalhana and Nyayachandrika Panjika of Sri Gayadasacharya on Nidanasthana ,Chaukhamba Orientalia Varanasi, edition reprint 2009,13/35,page no 322 .

6. Vagbhata Ashtanga Hridaya with Sarvanga Sundara commentary by Arunadatta and Ayurveda Rasayana of Hemadri, edited by Hari Sadasiva Sastri Paradakara, published by Chaukhamba Surbharathi Prakashan, Reprint 2010, Uthara Sthana Chapter 23, Shloka 20, Page No 859

7. Dandruff and sebborheic dermatitis: A Head Scracher by James. R. S. Schwartz, Yvonne. M. Deangles and Thomas L. Dawson Jr, Chapter 12, Page No 11.
8. Vagbhata Ashtanga Hridaya with Sarvanga Sundara commentary Arunadatta and Ayurveda Rasayana of Hemadri, edited by Hari Sadasiva Sastri Paradakara, Published by Chaukhamba Surbharathi Prakashan, Reprint 1982, Sutra Sthana, Chapter 12, Shloka 3, Page No 183.

9. Vagbhata Ashtanga Hridaya with Sarvanga Sundara commentary Arunadatta and Ayurveda Rasayana of Hemadri, edited by Hari Sadasiva Sastri Paradakara, Published by Chaukhamba Surbharathi Prakashan, Reprint 2010, Sutra Sthana, Chapter 15, Shloka 17, Page No 235.

10. Sahasrayogam with Sujanapriya commentary by K. V. krishnan Vaidhyar and S.Gopalapilla published by Vidyarambam publishers .Taila prakarana ,page no 287.

11. A Complete Treatise on Ayurveda Yogaratnakara, Edited by Ashakumari, P.V. Tewari, Published by Chaukamba Viswabharathi Varanasi, $1^{\text {st }}$ edition 2010, Chapter 30, Shloka 106, Page No 991.

12. Vagbhata Ashtanga Hridaya with Sarvanga Sundara commentary Arunadatta and Ayurveda Rasayana of Hemadri, edited by Hari Sadasiva Sastri Paradakara, Published by Chaukhamba Surbharathi Prakashan, Reprint 1982, Sutra Sthana, Chapter 20, Shloka 1, Page No278.

13. Govind Das Bhaisajya Ratnavali, Prof. Siddhinandan Mishra, Varanasi Chaukamba Prakashan 2015, Kushtarogadikara chapter 54, Shloka 114, Page No 866.

14. Chadrabhushan Jha Ayurvediya Rasa Shastra, Varanasi, Choukhamba Surbharathi Prakashan, 2015, Page No 449 .

15. Govind Das Bhaisajya Ratnavali, Prof. Siddhinandan Mishra, Varanasi Chaukamba Prakashan 2015, Kushtarogadikara chapter 54, Shloka 114, Page No 871.

16. Diseases of skin and cosmetics, Page 49.

\section{Source of Support: Nil \\ Conflict of Interest: None Declared}

How to cite this URL: Sruthi O: An Ayurvedic Approach On Darunaka - A Case Report. International Ayurvedic Medical Journal \{online\} 2020 \{cited November, 2020\} Available from:

http://www.iamj.in/posts/images/upload/5193 5198.pdf 